\title{
RUANG PASCAKOLONIAL DALAM KITCHIN KARYA YOSHIMOTO BANANA
}

\author{
Wury Dwiwardani \\ Sastra Jepang, Fakultas Ilmu Budaya UGM \\ Jln. Sosiohumaniora Bulaksumur Yogyakarta
}

\begin{abstract}
Abstrak
Pilihan Yoshimoto Banana pada sebuah ruang sebagai judul novelnya yaitu Kitchin atau Kitchen yang menggambarkan arti penting ruang bagi novel tersebut menjadi latar belakang penelitian ini. Tujuan dari penelitian ini adalah mengungkapkan respon terhadap kolonisasi kultural dalam ruang pascakolonial yang muncul dari novel Kitchin. Penelitian dilakukan dengan menganalisis hubungan satuan-satuan tekstual yang signifikan di dalam teks, serta mengaitkannya pula dengan data-data di luar teks dengan menggunakan teori pascakolonial tentang ruang. Hasil penelitian ini dapat disimpulkan sebagai berikut. Dalam novel Kitchin terdapat representasi dari konsep kolonial dan konsep tradisi. Di samping representasi dua kubu tersebut, muncul pula penggambaran kekacauan. Kekacauan ini merupakan wujud gagasan baru yang menolak untuk digabungkan dalam salah satu kubu yang membangun struktur oposisi antara kolonial dan tradisi. Dengan kekacauan ini muncul struktur baru yang tak hanya terdiri dari oposisi dua kubu, kolonial dan tradisi. Gagasan-gagasan baru ini terhubung pada upaya-upaya bertahan di tengah kondisi masyarakat yang telah terkolonisasi secara kultural.
\end{abstract}

Kata Kunci: kolonisasi kultural, ruang pascakolonial, Kitchin

\begin{abstract}
Yoshimoto Banana' choice on a space as the title of his novel, Kitchin or Kitchen, that describes the importance of space for the novel becomes the background of this research. Besides, this study is also grounded by a previous study conducted by Kazuo Nakajima and The aim of this study is to reveal the response toward cultural colonization emerging in postcolonial space of novel Kitchin. The study is conducted by analyzing the relationship of significant textual units in the text, as well as linking it with the data outside by using postcolonial theory about space. The results of this study can be summarized as follows. In Kitchin, there are representation of colonial concept and traditional concept. Besides the representation of the two groups, there are also depictions of chaos. It is a form of new ideas that refuse combination that build opposition between colonial structures and traditions. The chaos emerges a new structure which consists of more than two opposition; colonial and traditions. These new ideas are connected to efforts to survive in a society that has been colonized culturally.
\end{abstract}

Keywords: cultural colonization, postcolonial space, Kitchin.

\section{Pendahuluan}

Yoshimoto Banana dengan debut pertamanya, sebuah novel berjudul Kitchin, telah menarik perhatian pembaca dan kritikus sastra, baik dari dalam maupun luar negeri asalnya, Jepang. Tidak hanya berhasil mencapai jumlah penjualan yang memuaskan, karya ini juga telah mengantarkan Yoshimoto Banana menerima beberapa penghargaan, yang di antaranya adalah penghargaan dari jurnal sastra Jepang, Kaien, untuk penghargaan Japan's New Writers Prize pada tahun 1989, Izumi Kyoka Literary Prize pada bulan Oktober 1988, dan Scanno Literary Prize (Italia) pada tahun 1993, dan beberapa penghargaan lain (http://www. yoshimotobanana.com).

Walaupun sukses mencapai angka penjualan yang tinggi dan memperoleh berbagai penghargaan, Kitchin dengan popularitasnya banyak pula mendapat kritikan. Kisah-kisah dalam tulisan-tulisan Banana yang memiliki keterkaitan dengan billboard, iklaniklan televisi, musik pop, dan majalah fashion, dipandang oleh para kritikus sebagai sebuah penyerahan diri tanpa syarat pada kekuatan komersialisasi yang sering dianggap berada di balik produksi budaya populer (Treat, 1993: 360). Budaya populer dianggap identik dengan 
dominasi ideologi kapitalis yang memiliki tujuan meruntuhkan kepribadian yang otentik, dan menggantikannya dengan kepribadian kaum pekerja dan konsumen (Treat, 1993: 365). Oleh karena itu, bagi para kritikus sastra yang memiliki keyakinan bahwa setiap penulis memiliki tanggung jawab untuk menghasilkan karya-karya yang kritis dan bersifat introspektif pada gejala-gejala terjadinya perubahan sosial, karya-karya Banana, tidak dapat dianggap sepenuhnya sebagai sebuah karya sastra (Treat, 1993: 359-360).

Tak sepaham dengan pendapat di atas, muncul pula pandangan yang berbeda, seperti yang dikemukakan oleh Yoshimoto Takaaki, yang menyatakan bahwa budaya Jepang saat ini adalah suatu 'complex indeterminacy', sebuah budaya tanpa pusat yang tetap, tanpa hierarki. Kini budaya Jepang merupakan sebuah budaya dimana berbagai kelas, subkultur, dan wacana beredar dan bersaing dengan klaim setara atas legitimasinya (Yoshimoto Takaaki dalam Treat, 1993: 359). Dalam karya-karya yang dianggap sebagai bagian budaya populer terdapat kemungkinan-kemungkinan reartikulasi atas berbagai peran yang ditujukan atau disematkan kepada masyarakat (Treat, 1993: 366). Tentu kemungkinan-kemungkinan itu terdapat pula dalam Kitchin.

Salah satu hal yang menarik dari Kitchin adalah novel tersebut mengangkat nama salah satu ruangan dalam rumah, yaitu Kitchin yang berasal dari kata Kitchen, dapur, sebagai judul. Pilihan tersebut mengindikasikan arti penting ruang bagi pemaknaan novel. Karena arti penting ruang tersebut, maka diperlukan penelitian terkait ruang dalam novel Kitchin.

Penelitian atas ruang dalam novel karya-karya penulis Jepang pernah dilakukan sebelumnya oleh Nakajima Kazuo dan William Weaver yang dipublikasikan dalam tulisan mereka yang berjudul The Concept of Space in Modern Japan. Nakajima dan Weaver menemukan adanya kegelisahan atas ruang sebagai akibat dari pengaruh budaya Barat yang muncul dalam beberapa novel Jepang. Apa yang dikemukakan dalam penelitian, bagaimana kondisi kegelisahan atas ruang, sebagai akibat perubahan yang terjadi karena pengaruh budaya Barat, menjadi petunjuk bahwa masyarakat Jepang telah mengalami kolonisasi secara kultural oleh budaya Barat. Kolonisasi tidak hanya terbatas dalam wujud perampasan kedaulatan pada wilayah teritori, namun juga dapat berwujud penjajahan pikiran, jiwa, dan budaya (Nandy dalam Gandhi, 2006: 20). Kegelisahan atas ruang tersebut merupakan reaksi atas berbagai perubahan yang terjadi pada ruang akibat pengaruh kolonisasi budaya. Oleh karena itu, dapat disimpulkan bahwa novel-novel tersebut merupakan novel-novel pascakolonial.

Di akhir tulisannya, Nakajima dan Weaver menyebutkan bahwa novel Kitchin merupakan salah satu novel yang juga menunjukkan adanya perhatian pada perbedaan spasial. Walau tidak disertai dengan penjelasan/ penjabaran, disebutkan bahwa Kitchen menggunakan dapur yang modern, asing, bergaya Amerika, untuk menandai gaya radikal dari tokoh protagonis dari novel (Nakajima, 1996: 72). Dengan demikian, dapat disimpulkan bahwa Kitchin merupakan salah satu contoh novel pascakolonial. Arti penting ruang dalam novel Kitchin yang merupakan novel pascakolonial menjadi latar belakang dilakukannya penelitian ini, penelitian tentang ruang dalam sudut pandang pascakolonial. Dalam tulisan ini akan dipaparkan bagaimana respon spasial terhadap kolonisasi kultural yang muncul dalam novel Kitchin karya Yoshimoto Banana.

\section{Ruang Pascakolonial}

Pendekatan yang digunakan pada penelitian ini mengacu pada teori politik ruang pascakolonial yang dikemukakan oleh Sara Upstone dalam penelitiannya pada novel-novel pascakolonial. Penelitian Sara Upstone tersebut dituangkannya dalam tulisan bertajuk Spatial Politics in Postcolonial Novel.

Kajian dalam pandangan pascakolonial tentang ruang yang dilakukan oleh Sara Upstone memberi perhatian pada upaya-upaya kontrol 
dalam bentuk persetujuan atas pemikiranpemikiran atau konsep-konsep yang ditanamkan oleh pihak penguasa kolonial sebagai strategi penguasaan dan pelestarian kekuasaan. Kontrol yang dilakukan oleh penguasa kolonial dilakukan dalam wilayah berbatas jelas dan tetap. Oleh karena itu, salah satu konsep penting yang digunakan untuk kepentingan kolonial adalah konsep batas. Pemahaman dan persetujuan tentang batas sangat vital untuk melakukan identifikasi atas wilayah teritori dan melindungi kekuasaan atas wilayah tersebut. Status wilayah teritori yang terpetakan dengan pasti dan jelas merupakan satu bagian yang integral dalam definisi tentang koloni, seperti juga yang tercantum dalam Oxford English Dictionary, yang mengartikan koloni bukan hanya mencakup sebuah komunitas masyarakat tertentu, namun juga wilayah dari komunitas tersebut (Upstone, 2009: 4).

Konsep ruang berbatas ditanamkan pada masyarakat sebagai sesuatu yang tetap, terkontrol, absolut, dan natural. Fakta bahwa kondisi tersebut merupakan bentukan terkaburkan bersama dengan meresapnya konsep kolonial tersebut (Upstone, 2009: 4).

Dalam wilayah yang teritorinya punya batas-batas yang jelas seperti yang tersebut di atas, hukum-hukum, agama, pendidikan, dan praktik-praktik kehidupan sosial yang dimiliki oleh penguasa kolonial menjadi superior (Upstone, 2009: 5). Berbagai persetujuan terhadap konsep-konsep yang menguntungkan penguasa kolonial diupayakan tertanam dalam masyarakat dengan cara membentuk idealisasi-idealisasi, harmonisasi-harmonisasi di kehidupan dalam berbagai aspeknya.

Usaha-usaha penguasa kolonial menanamkan berbagai konsep untuk mengamankan kekuasaan, ternyata tak satu pun berhasil mencapai totalisasi secara menyeluruh. Konsep baru yang ditanamkan oleh penguasa kolonial memang terlihat di permukaan, namun tak dapat menghilangkan jejak-jejak masa lalu. Apa yang telah 'tertulis' sebelumnya berusaha dikaburkan, digantikan dengan representasi baru, namun penghapusan tersebut selalu meninggalkan bekas (Upstone, 2009: 7).

Konsep-konsep kolonial telah menutupi realita sebenarnya yang lebih kacau/ chaotic pada ruang. Berbeda dengan harmonisasi dan idealisasi ala kolonial, ruang bersifat lebih cair dan chaotic/ kacau dalam imaji pascakolonial (Upstone, 2009: 11). Sara Upstone menawarkan gagasan bahwa dengan merebut kembali kecairan ruang yang telah ditolak oleh konsep kolonial dalam gagasan ruang berbatasnya, dan dengan memberi lokasi-lokasi fungsifungsi politis, penulis-penulis pascakolonial menciptakan ruang sebagai tempat berbagai kemungkinan dan resistensi (Upstone, 2009: 11).

\section{Ruang Pascakolonial dalam Rumah}

Rumah adalah salah satu konstruksi yang memegang peran menjalankan fungsi politis dalam menegakkan nilai-nilai kolonial, dan peran ini ditampilkan pada rumah secara paradoks dalam idealisasi dan apolitisasi (Upstone, 2009: 115). Penguasa kolonial menggunakan rumah untuk mempropagandakan wacana negara kolonial. Rumah menjadi miniatur dari tabulasi kolonial atas ruangan, metafora dari wilayah koloni. Kondisi awal dari rumah yang lebih cair dikaburkan. Harmoni yang ideal tentang rumah dimunculkan dengan mempropagandakan pandangan bahwa rumah adalah lokasi penanaman nilai-nilai dan tingkah laku yang dianggap krusial untuk membentuk dan mempertahankan identitas nasional, serta merupakan perlindungan yang diperlukan dari perubahan sosial dan kondisi ekonomi yang tak terduga (Upstone, 2009: 117).

Rumah pascakolonial menolak perannya untuk mempropagandakan wacana kolonial dengan menolak fungsi metaforisnya sebagai metafora dari koloni dengan berbagai idealisasinya. Dengan menolak peran tersebut, rumah akan terbuka bagi beragam makna yang berbeda, dan tidak tertutup dalam berbagai aturan melainkan terbuka untuk berbagai kemungkinan (Upstone, 2009: 119).

Penolakan terhadap idealisasi kolonial adalah salah satu bagian dari elemen tulisan 
pascakolonial, namun tidak hanya itu saja. Politisasi rumah bukan hanya berisikan dorongan untuk menghilangkan idealisasi, namun juga berisikan pemahaman-pemahaman baru. Berbagai makna yang direpresi dalam penulisan kolonial tentang rumah disingkap, tak lagi dipaksa untuk menjadi metafora dari kolonial, sehingga rumah dapat muncul untuk mewakili kepentingan-kepentingan lain.

\section{Ruang Pascakolonial dalam Dapur}

Rumah dalam tradisi Jepang pada awalnya merupakan entitas yang lebih cair. Dalam rumah tradisional Jepang, selain toilet dan kamar mandi (bila ada), tidak terdapat tempat yang betul-betul tertutup (Nakajima, 1997: 69). Kontinuitas antara eksterior dan interior tampak jelas di tiap bagian dari rumah, ruang bukanlah bunker yang tertutup dengan tembok-tembok, ruang bersifat lunak, dimana batas-batas dengan dunia luar hanya berupa kolom-kolom dan atap. Di dalam rumah, kamar-kamar hanya dibatasi dengan pembatas yang rapuh, tak berkunci ( Nakajima, 1997: 69). Kondisi rumah Jepang tradisional dengan pembatas-pembatas ruang yang tidak tetap seperti tersebut di atas tidak sesuai bagi fungsi rumah sebagai metafora dari koloni, yang mensyaratkan batas-batas yang jelas, baik fisik maupun fungsi.

Dalam konsep spasial kolonial tentang rumah, setiap ruang memiliki batas yang tetap dengan aturan-aturan yang disampaikan dalam idealisasi-idealisasi, di antaranya seperti yang dituliskan oleh R. Temple-Wright, seorang wanita dari Inggris pada akhir abad 19, "Thing you must never, under any circumstances, allow in your kitchen are, a hookah, a bed, and the personal apparel of the cook and his mate" (dalam Upstone 2009: 118). Salah satu larangan, batas yang sama sekali tak boleh dilanggar dalam kondisi apapun, yang disampaikan dalam pernyataan di manual tersebut adalah meletakkan tempat tidur di dapur. Yoshimoto Banana menciptakan chaos untuk melanggar batas-batas kolonial itu dengan menuliskan kisah yang berkebalikan dengan larangan tersebut. Dikisahkan Mikage, tokoh wanita dalam Kitchin yang sedang melewati masa sulit dalam hidup karena satu-satunya keluarganya yang tersisa, yaitu neneknya, baru saja meninggal dunia, merasa nyaman berada di dapur dan hanya bisa tidur di tempat itu.

Di sisi yang lain, terkait batas dan penggunaan ruang sebagai lokasi untuk tidur, dalam rumah tradisional Jepang terdapat tradisi yang berbeda dengan konsep batasbatas kolonial. Berbeda dengan tradisi di Barat, konsep dasar dari ruang-ruang tradisional Jepang adalah menyelenggarakan berbagai aktivitas di lantai. Lantai dilengkapi dengan alas yang disebut tatami, yang dapat mengakomodasi berbagai aktivitas. Tanpa adanya berbagai perabot untuk duduk, akhirnya ruang-ruang tradisional Jepang dapat dengan mudah berubah fungsi untuk berbagai aktivitas, termasuk tidur. Sehingga, dimungkinkan ruang utama (living room) digunakan pula sebagai ruang tidur pada malam hari. Untuk mendukung transformasi tersebut, ruang multi fungsi ini bahkan dilengkapi dengan lemari-lemari penyimpanan alas tidur yang disebut oshi-ire (Engel, 1988: 228).

Bila dilihat dari bentuk fisik pembatas di rumah tradisional, tradisi Jepang terkait dengan pembatasan ruang lebih longgar dan cair. Namun demikian, bukan berarti ruangruang tersebut tak berbatas. Saat partisi dibuka sekalipun, para penghuni rumah masih memiliki batas-batas psikologis, berupa rel-rel kayu yang membedakan kamar-kamar dengan koridor dan berperan sebagai pembatas. Melewati batas tersebut tanpa ijin dari penghuni kamar dianggap sebagai hal yang tak pantas dilakukan oleh penghuni rumah (Engel, 1988: 248).

Dalam rumah tradisional Jepang dikenal ruangan-ruangan yang dapat bertransformasi fungsi, termasuk sebagai lokasi tidur. Arsitektur Jepang menawarkan keberhasilan dalam fleksibilitas spasial, yang tak hanya disebabkan oleh partisi yang dapat dipindahkan, namun lebih kepada aturan umum yang memproduksi ruangan-ruangan dengan kualitas spasial yang seimbang, sehingga dapat melebur satu sama lain dengan harmonis (Engel, 1998: 252). 
Kondisi demikian berbeda dengan arsitektur rumah di Barat dimana perbedaan dalam pemaknaan ruang secara kualitatif diekspresikan melalui skala, perlakuan, dan dekorasi. Ruang dibedakan kualitasnya dan pencampuran maupun penambahan ruang akan menciptakan ketegangan dan ketidakharmonisan (Engel, 1998: 249). Ditambah lagi dengan perbedaan akses keluar masuk, serta jendela yang memiliki proporsi yang berbeda-beda, maka ruanganruangan sejak awal memiliki tujuan, terorientasi, dan setiap ruangan memiliki aksen tertentu (Engel, 1998: 249). Pengaturan rumah yang sesuai dengan konsep-konsep batas kolonial.

Kisah Mikage berpindah tidur membangkitkan kenangan tentang kecairan dalam rumah. Namun demikian, dari kisah tersebut muncul pula kekacauan karena dalam arsitektur tradisional Jepang pun dikenal batasbatas walau bukan merupakan batas fisik yang berbentuk vertikal yang tetap. Lokasi tidur yang dipilih adalah dapur, tempat yang pada masa lalu pun tidak lazim dipergunakan untuk tidur. Dapat disimpulkan bahwa aktivitas tidur di dapur tersebut menjadi terobosan pula bagi konsep dapur tradisional pada masa lalu. Dengan demikian, kisah Mikage berpindah lokasi tidur ke dapur merupakan pelanggaran terhadap konsep ruang berbatas yang tetap dari kolonial, dan juga batas psikologis dari ruang tradisi Jepang. Meskipun tampak jejakjejak masa lalu, namun memang tak mungkin kembali lagi ke masa lalu, mendapatkan kembali apa yang telah hilang. Kekacauan yang dimunculkan oleh Yoshimoto Banana ditujukan untuk memunculkan pemahaman-pemahaman baru.

Seiring berbagai perubahan yang masuk bersama dengan konsep-konsep kolonial dan budaya modern, banyak bagian dari kehidupan masyarakat tradisional yang hilang. Rasionalitas yang menjadi salah satu nilai ideal yang ditanamkan di rumah-rumah merupakan salah satu penyebabnya. Ura dan Omote, salah satu konsep spasial tradisi Jepang, mulai tak mendapat tempat dalam rumah-rumah dan apartemen modern Jepang. Mikage menemukan zona ura miliknya dalam apartemen modern di dapur lewat chaos yang diciptakan Yoshimoto Banana dalam fungsi dapur. Ia memunculkan kenangan tentang zona 'ura', ruang untuk sejenak melarikan diri, menjadi terapi untuk menghadapi berbagai perubahan, proses penerimaan untuk hal-hal yang telah hilang dan tak mungkin dapat kembali lagi, untuk kemudian dapat terus melanjutkan hidup.

\section{Perlengkapan Rumah dalam Ruang Pascakolonial}

Apartemen keluarga Tanabe yang menjadi salah satu latar adegan merupakan apartemen modern, dengan dapur modern, dilengkapi berbagai perangkat rumah yang memberi fasilitas bagi aktivitas untuk tak lagi dilakukan langsung di atas lantai, tak seperti kebiasaan dalam rumah tradisional Jepang. Sofa merupakan salah satu perabot rumah modern yang digambarkan dalam Kitchin. Tradisi yang dilakukan masyarakat Jepang masa lalu dalam rumah mereka berbeda dengan idealisasi dalam rumah yang ditanamkan oleh pengaruh negaranegara Barat yang masuk ke Jepang. Pengaruh atas penanaman idealisasi tersebut muncul pula dalam novel pada penggambaran sofa seperti dalam kutipan berikut ini.

“おじやまします、とあがったそこには、 実に妙な部屋だった。

まず、台所へ続く居間にどかんとある巨 大のソファーに目がいった。その広い台 所の食器棚を背にして、テーブルを置く でもなく、じゅうたんをひくでもなくそれ はあった。ベージュ布ばりで、CMに出て きそうな、家族みんなですわって

$T \vee$ 見そうな、横に日本で飼えないくら い大きいな犬がいそうな、本当に立派な ソファーだった"

["Begitu masuk, tampaklah sebuah ruangan yang tak biasa. Pertama-tama, di ruang tamu yang terhubung langsung dengan dapur terlihat sebuah sofa yang sangat besar. Sofa itu ada di tempat itu, berlatar belakang rak berisi peralatan makan di dapur yang luas, tanpa meja, 
dan tak beralaskan karpet. Berlapis kain kuning gading, seperti layaknya sofa yang muncul di iklan-iklan, tempat berkumpul seluruh keluarga sambil nonton TV, dengan seekor anjing besar yang tak mungkin dipelihara di Jepang di sampingnya. Betul-betul sebuah sofa yang mewah”] Yoshimoto, 1991: 13).

Sofa melekat pada imajinasi tentang keluarga bahagia, dan imajinasi itu muncul begitu saja saat Mikage melihat sebuah sofa besar di kediaman keluarga Tanabe. Imajinasi tersebut merupakan hasil penanaman idealisasi, terkait sebuah kondisi yang melibatkan unsurunsur budaya asing. Namun demikian, walaupun muncul imajinisasi tentang hal yang ideal terkait dengan sofa mewah itu, dalam waktu bersamaan muncul pula kesadaran bahwa pemandangan sebuah sofa besar tersebut bukan pemandangan yang biasa bagi Mikage. Sesuatu itu terasa tidak lazim tentu karena berbeda dengan hal yang diyakini selama ini. Ini merupakan gejala adanya nilai-nilai lama yang ditutup dengan idealisasiidealisasi baru.

Perubahan tentang imaji ideal tak lepas dari peran media massa, dan di sisi lain dari imaji ideal yang ditampilkan oleh media massamedia massa dapat kita lihat adanya pergeseran idealisasi yang berlaku di masyarakat, seperti yang dituliskan oleh Nakagawa Takeshi (2005: 113) sebagai berikut.

"Of course,this largerly due to the influence of dramas potraying family life, both in the movies and on TV. Whenever the setting was the home of an ordinary urban family,perhaps a tradesman's or shopkeeper's, before or shortly after World War II,most of the scenes would take place in the chanoma. This was partly because,for some reason, the action tended to take place in the mealtimes. The moment one thinks of these films or serials, certain familiar images of the chanoma come to minc; the cheerful give and take around the table, a small yard glimpesed beyond a veranda, the comings and goings from the adjacent shop.

But the time that families spent together took on a subtly different quality once a large TV console was set down in middle of the room and a lifestyle based on Western style tables and chairs replaced the one associated with a low table on tatami. By this point, the room had ceased to be a chanoma and should probably be called ribingu-rümu (living room) or famiri rümu (family room) instead." (Nakagawa, 2005: 113).

Chanoma yang berarti tea room, ruang minum teh, biasanya dihubungkan dengan ruang keluarga di rumah jaman Meiji. Ruang yang serasi dilengkapi dengan meja teh bundar yang rendah (Nakagawa, 2005: 112) ini merupakan ruang yang terutama diasosiasikan dengan ruang tempat keluarga makan dan berkumpul bersama-sama (Nakagawa, 2005: 112). Dari kutipan di atas tampak bahwa ruang yang dikaitkan dengan imaji ideal keluarga telah berubah dari chanoma bergaya Jepang menjadi living room dengan gaya Barat.

Reaksi Mikage ketika melihat sebuah sofa di rumah keluarga Tanabe menjadi petunjuk bahwa konsep-konsep ideal baru telah masuk di kehidupan masyarakat, muncul di permukaan, dan menutup konsep-konsep tradisi. Namun demikian, konsep-konsep tradisi tak sepenuhnya hilang. Jejak-jejak masa lalu digambarkan oleh Yoshimoto Banana dalam kenangan-kenangan tentang ruang bergaya tradisi lama, dalam sebuah mimpi yang melibatkan aktivitas yang terhubung dengan budaya lama, dan melalui penggambaran munculnya rasa ganjil ketika Mikage melihat sofa yang bukan merupakan produk budaya lama.

Selain sofa, dalam apartemen milik keluarga Tanabe banyak dimunculkan bendabenda produk budaya Barat, produk-produk budaya modern yang diusung oleh budaya Barat, teknologi maju yang mengedepankan fungsi praktis seperti televisi, blender, dan mesin faksimile. Kemunculan berbagai produk-produk budaya dalam novel menjadi gambaran bahwa dalam masyarakat Jepang, seperti di berbagai belahan dunia yang lain, budaya yang dibawa oleh asing yaitu budaya Barat beserta produkproduknya, menguasai atau mengkolonisasi kehidupan masyarakat.

Dalam kisah di novel, walaupun di 
awal Mikage merasa ganjil melihat sofa dalam apartemen milik keluarga Tanabe, ia kemudian dapat menerima kehadiran sofa itu dengan baik, memanfaatkannya, dan bahkan merasa nyaman saat menggunakannya. Sofa itu menjadi tempat tidur Mikage selama ia tinggal di kediaman keluarga Tanabe. Hal yang sama digambarkan dalam Kitchin pada beberapa benda-benda lain dalam rumah. Benda-benda tersebut mewarnai kehidupan sehari-hari para tokoh dalam Kitchin, diterima dengan baik, dan bahkan, terutama produk-produk tekhnologi modern, dapat memunculkan dorongan impulsif untuk memilikinya walau tak dilandasi kebutuhan pada fungsi praktis yang merupakan tujuan dibuatnya benda-benda tersebut

Ada hal berbeda terkait dengan penggambaran sofa dalam Kitchin. Yoshimoto Banana meletakkan sofa dalam kisah buatannya tepat di sebelah dapur, tanpa sekat yang membatasi. Kondisi tersebut mengantar sofa kepada peran yang lebih dari hanya sekedar pemenuhan kebutuhan praktisnya sebagai tempat duduk.

“そして、今宵私の寝床となったソファー にたどりつくと、電気をけした。

空べで、かずかな明かりに浮かぶ植物た ちが10Fからの豪華な夜景にふちどられ てそっと息づいていた。夜景一もう、雨は あがって湿気を含んだ透明な大気にきら きら輝いて、それはみごとに映っていた。

私は毛布にくるまって、今夜も台所のそ ばで眠ることがおかしくて笑った。しい 、孤独がなかった。私は待っていたのかも しれない。今までのことも、これからのこ ともしばらくだけの間、忘れられる寝床だ けを待ち望んでいたのかもしれない。と なりに人がいては淋しさが増やすからい けない。でも、台所があり、植物がいて、同 じ屋根の下には人がいて、静かで....... ストだった。ここはべストだ。安心して私 は眠つた。”
[“Kemudian, kudekati sofa yang akan menjadi tempat tidurku malam ini dan kumatikan lampu. Tanaman-tanaman di sisi jendela, dalam cahaya yang redup, tampak terapung, dibingkai oleh pemandangan malam yang indah di lantai 10. Kutarik nafas perlahan-lahan. Pemandangan malam, dalam suasana setelah hujan mereda, berkilauan dalam udara yang lembab, tertangkap jelas dari jendela. Berbalut selimut, aku tersenyum geli karena ternyata malam ini pun aku tidur di dekat dapur. Tapi tanpa rasa kesepian. Mungkin ini yang kutunggu selama ini. Mungkin aku mengharapkan ada suatu tempat di mana aku bisa sejenak melupakan peristiwa yang telah terjadi, dan apa yang akan terjadi. Bila ada seseorang tidur di sisi ku perasaan sepi justru akan bertambah. Namun di sini, ada dapur, ada tanaman-tanaman, ada seseorang berada di bawah atap yang sama, dalam ketenangan..... the best. Tempat ini benar-benar the best. Dalam damai aku tertidur'] Yoshimoto, 1991: 2526).

\section{“その台所と同じくらいに、田辺家のソフ アーを私は愛した。そこで眠りが味わえ た。草花の呼吸を聞いて、カーテンの向こ うの夜景を感じながら、いつもすっと眠 れた”}

["Sono daidokoro to onaji kurai ni, Tanabe ya no sofaa o watashi wa aishita. Soko de nemuri ga ajiwaeta. Kusabana no kokyun o kiite, kaaten no mukoo no yakei o kanjinagara, itsumo sutto nereta']

["Aku cinta sofa di rumah Tanabe kira-kira sama seperti aku mencintai dapur itu. Di sofa itu aku bisa merasa mengantuk. Sambil mendengarkan nafas bunga-bunga serta menikmati pemandangan malam di balik tirai, aku selalu bisa cepat tertidur'] (Yoshimoto, 1991: 33).

Lemari pendingin atau kulkas, benda lain yang merupakan produk teknologi modern, dalam novel Kitchin juga dikisahkan mendapatkan peran lain di samping fungsi praktisnya, seperti yang dilihat dalam kutipankutipan berikut. 
“ライナスのように毛布にくるまって眠 る。冷蔵庫のふ一んという音が孤独な思 考から守った。”

["Lalu, seperti Linus, aku tidur meringkuk dibalut selimut. Dengungan kulkas melindungiku dari rasa sepi'] Yoshimoto, 1991: 8).

Yoshimoto melakukan pelanggaran atas idealisasi-idealisasi kolonial dengan pilihannya menggambarkan sofa yang diletakkan dengan latar belakang dapur, dan memberi benda berupa lemari es dengan fungsi lain yang bukan merupakan fungsi praktis mekanis. Fungsi di luar fungsi praktis mekanis tersebut justru berperan lebih utama dalam memberi ketenangan dalam hidup tokoh novel, Mikage Sakurai. Dalam hal ini terlihat kembali upaya untuk menolak peran yang disematkan pada rumah sebagai kaki tangan kolonial dan upaya untuk memberi rumah, dan perangkat yang ada di dalamnya makna/ peran yang lain.

Penempatannya yang dekat dengan dapur membuat sofa dalam keluarga Tanabe bagi Mikage berfungsi pula sebagai ura, seperti dapur. Di sofa milik keluarga Tanabe, Mikage merasa tenang dan nyaman, dapat merasa mengantuk, tertidur nyenyak, dan bahkan bermimpi dalam tidurnya. Sofa seperti juga dapur, adalah tempat Mikage melepaskan diri dari aktivitas dan kenyataan hidup yang harus dilaluinya setiap hari, tempat ia dapat sejenak melupakan peristiwa-peristiwa yang telah terjadi dan akan terjadi. Oleh karena itu, Mikage mencintai sofa milik keluarga Tanabe sama seperti ia mencintai dapur. Kulkas diterima bukan hanya sebagai lemari pendingin makanan dan minuman, namun juga diberi peran lain, suara dengungannya mampu melindungi Mikage dari perasaan sepi.

Ketika berbagai perubahan terjadi pada tempat tinggal di Jepang, banyak hal menjadi praktis dan nyaman. Namun, di sisi lain, banyak pula hal yang memudar dan bahkan hilang. Tempat tinggal masa kini di Jepang terutama berperan sebagai instrumen bersifat fungsional, dan mekanis yang memberi fasilitas pada kebutuhan praktis manusia seperti makan, tidur, bekerja, melihat, menikmati, dan dapat juga tempat tinggal menawarkan kualitas visual-estetis (Engel, 1988: 232). Namun, di balik itu, tempat tinggal-tempat tinggal tersebut kehilangan kedalaman filosofis yang disampaikan oleh rumah-rumah masa lalu.

Dalam novel Kitchin, tergambar penerimaan para tokohnya dengan sangat baik pada berbagai produk budaya Barat, yang terhubung juga pada penerimaan pada perubahan perilaku. Penerimaan atas kondisi saat ini diwarnai dengan jejak-jejak masa lalu berupa kenangan-kenangan yang melibatkan ruang-ruang dalam rumah tradisi dan perilakuperilaku yang lahir dari rumah-rumah tradisi tersebut. Jejak-jejak masa lalu ini menunjukkan bahwa penanaman konsep-konsep kolonial terbukti tidak dapat mencapai totalisasi. Meski demikian, kenangan-kenangan masa lalu yang muncul tersebut bukan merupakan penolakan terhadap produk budaya kolonial, tidak ditujukan sebagai usaha kembali pada kondisi masa lalu, karena memang tak mungkin mendapatkan kembali apa yang telah hilang. Perubahan-perubahan yang tak terelakkan lagi harus dihadapi, dan yang diperlukan untuk itu adalah upaya-upaya untuk tetap bertahan dalam berbagai perubahan tersebut.

Konsep-konsep kolonial yang mengedepankan rasionalitas, fungsi-fungsi mekanis praktis dari berbagai produk, mau tak mau telah masuk dan menjadi hal yang terasa alamiah dalam kehidupan sehari-hari. Fokus pada fungsi-fungsi mekanis praktis tersebut kemudian nyaris menghilangkan nilainilai filosofis yang pada masa sebelumnya menjadi bagian penting dari produk-produk budaya tradisi. Reaksi terhadap konsep-konsep kolonial tersebut digambarkan dalam novel dengan memberikan benda-benda produk budaya kolonial yang menjadi bagian kehidupan mereka, masyarakat Jepang saat ini, peran-peran lain di samping fungsi-fungsi mekanis praktis. 'Kecanduan' para tokoh pada berbagai produk 
yang dikisahkan dalam novel, rasa tenang sang tokoh ketika mendengar dengung lemari es, menunjukkan bahwa peran dari bendabenda produk budaya asing tersebut telah lebih dari sekedar pemenuhan pada kebutuhan fungsional praktis. Penambahan peran-peran ini memberi kekuatan untuk bertahan pada kondisi masa kini, menutup lubang-lubang yang muncul akibat meluasnya nilai-nilai baru, dan menerima kenyataan bahwa apa yang telah hilang selamanya tak mungkin dapat kembali lagi.

\section{Keluarga dan Wanita dalam Ruang Pascakolonial}

Konsep-konsep rumah yang ditanamkan pada rumah membawa implikasi pada peran wanita dalam rumah. Salah satu dampak dari pembagian divisi-divisi dan idealisasi dalam ruang domestik adalah terbentuknya ruangruang gender yang eksplisit, dan menempatkan wanita dalam jantung proyek imperial (Upstone, 2007: 266). Ketika pria bertanggung jawab untuk menjaga keteraturan politis dan publik, untuk menutupi chaos/ kekacauan, maka wanita memiliki tugas untuk melakukan hal yang sama di dalam rumah, menyediakan perlindungan dari berbagai pergulatan pasar (di luar rumah), dalam ruang yang harmonis, dan terorganisasi dengan kaku (Upstone, 2009: 118). Rumah yang dipisahkan dengan politik ruang publik, digambarkan dalam berbagai idealisasi, harmonisasi tempat tinggal dengan batas-batas yang jelas dan tetap, bersih, teratur, dan wanita lah yang bertanggungjawab dalam mewujudkannya. Menjadi pengatur rumah yang handal adalah bagian dari tugas istri dalam misi menciptakan 'masyarakat yang beradab' (civilising mission) (Upstone, 2009: 118). Kondisi tersebut menciptakan hubungan metaforis, seperti perjuangan kolonial dalam ekspansi teritorinya, maka tugas istri adalah melakukan perjuangannya melawan kondisi-kondisi domestik yang tak wajar (Upstone, 2009: 118).

Penjelasan di atas menunjukkan bahwa wanita, walaupun dipisahkan dengan dunia di luar rumah, namun di dalam rumah ia memiliki kekuatan melakukan kontrol untuk menciptakan tempat tinggal yang rapi, bersih, teratur, terkontrol, yang menjadi tolak ukur untuk keadaan yang 'beradab'. Jepang masa lalu, dalam budaya patriarkinya, memiliki kondisi yang berbeda. Kepada wanita diajarkan bahwa tugas utama mereka dalam kontribusinya bagi kelangsungan keluarga adalah menjalankan prinsip ketaatan, yaitu yang pertama taat kepada ayah saat mereka lajang, taat kepada suami saat mereka telah menikah, dan akhirnya taat kepada anak laki-laki ketika mereka telah menjanda (Hendry, 1987: 34). Seorang istri memiliki berbagai fungsi, mulai dari pengurus rumah tangga dan melayani seluruh anggota keluarga terkait berbagai kebutuhan seperti makanan, pakaian, kebersihan, juga sebagai ibu bagi anakanak, nyonya rumah, penjamu/ penghibur tamutamu, pembantu dalam pekerjaan di sawah, dan pasangan bagi suaminya, dan tak ada tempat atau waktu khusus untuk mereka (Engel, 1988: 227). Prinsip-prinsip rumah tinggal di Barat yang di antaranya lahir dari penghargaan atas tempat wanita di rumah tak berlaku di rumah tradisonal Jepang (Engel, 1988: 227). Di ruangruang utama, tak seperti di rumah-rumah Barat, dalam rumah tradisional Jepang sulit ditemukan atmosfer wanita (Engel, 1988: 228). Ruanganruangan tradisional Jepang bernafaskan kesimple-an dan kepraktisan kaum pria. Minimnya atmosfer wanita dalam ruang-ruang di Jepang menunjukkan minimnya otoritas wanita dalam rumah.

Dua keluarga utama yang dikisahkan dalam novel Kitchin adalah keluarga-keluarga kecil, keluarga modern dengan keterikatan yang minim dengan jaringan keluarga besar seperti halnya keluarga tradisional Jepang dimana keluarga juga merupakan unit-unit usaha yang terkait satu sama lain, dua keluarga kecil yang tak jelas lagi siapa yang berperan sebagai kepala keluarga. Kisah dalam Kitchin juga tak menggambarkan peran wanita sebagai penjaga idealisasi kolonial dalam rumah yang terpisah dari dunia luar, seperti yang ditanamkan oleh prinsip-prinsip kolonial.

Yoshimoto Banana menghadirkan 
kekacauan melalui sosok Eriko, seorang wanita transgender. Dalam novel Kitchin, di rumah keluarga Tanabe tak jelas lagi siapa pemegang peran sebagai kepala keluarga. Dalam tradisi Jepang, selalu pria yang menjadi kepala keluarga. Setelah ayah, prioritas utama jatuh ke anak laki-laki pertama. Dengan demikian, dari yang terlihat di permukaan, Yuuichi lah yang memenuhi syarat untuk berperan sebagai kepala keluarga. Tetapi apakah betul demikian? Walaupun Eriko sosok fisiknya adalah perempuan, tetapi ia terlahir sebagai laki-laki, lelaki yang juga perempuan. Walaupun sosok fisiknya seorang ibu, tetapi fakta bahwa Eriko adalah ayah biologis dari Yuuichi tak berubah, seorang ibu yang juga ayah biologis. Muncul kebingungan-kebingungan, seperti yang terlontar dalam salah satu ucapan Yuuichi, "Apa bisa kaupanggil sosok seperti dia ayah? ". Chaos terjadi.

Kekacauan yang dimunculkan oleh Yoshimoto Banana terhubung pada bentuk penolakan atas peran dalam rumah yang didasarkan atas perbedaan gender, seperti yang disyaratkan oleh kedua konsep, kolonial dan tradisi. Penolakan atas peran dalam rumah ini merupakan satu pemahaman baru, yang tak sesuai dengan idealisasi kolonial.maupun nilainilai tradisi, sebagai satu bentuk resistensi.

\section{Konsep Uchi dan Soto dalam Ruang Pascakolonial}

Uchi secara sederhana dapat diterjemahkan dalam Bahasa Indonesia sebagai 'dalam', dan Soto adalah lawan katanya, yaitu 'luar'. Walaupun di rumah berarsitektur tradisional Jepang pemisahnya antara interior dan ekterior bukan berupa dinding yang kokoh, kondisi tersebut tak serta-merta menunjukkan bahwa dalam pemikiran penghuni rumahrumah tradisional Jepang tidak terdapat pembeda antara dalam dan luar, uchi dan soto. Hubungan spasial antara ekterior dan interior rumah memang tidak dikontrol oleh partisi vertikal berupa sebuah dinding, namun sebagai gantinya terdapat lantai dan atap yang memberi tanda perbedaan ruang interior dan eksterior, dan bahkan ketika semua panel-panel pembatas dipindahkan, tak akan meniadakan perasaan berada di dalam (Engel, 1998: 248).

Kesadaran tentang keberadaan di dalam atau uchi, dan di luar atau soto diperdalam oleh berbagai nilai yang terkait dengannya. Bagi masyarakat Jepang, konsep uchi dan soto memegang peranan penting dalam kehidupan sosial. Konsep ini diperkenalkan dari generasi ke generasi, dan dilestarikan melalui penanaman nilai-nilai yang diajarkan dan diterapkan sejak masa belia. Perbedaan antara uchi dan soto terhubung dengan adanya perbedaan sikap yang dilakukan saat menghadapi anggota $u c h i$ dan soto. Uchi dan soto tak hanya terkait dengan suatu lokasi, dalam dan luar, namun juga meliputi anggota-anggotanya, anggota-anggota dari $u c h i$ yang beropososisi dengan anggota-anggota dari soto. Uchi mewakili anggota-anggota dari rumah atau suatu kelompok tertentu yang beroposisi dengan anggota-anggota soto, yaitu dunia di luar rumah atau di luar suatu kelompok. Perbedaan ini merujuk pada perbedaan antara tatemae atau sikap untuk publik, dan honne atau perasaan sebenarnya, (Hendry, 1987: 43). Idealisasi bahwa sikap-sikap yang tepat sesuai dengan posisinya merupakan tindakan yang seharusnya dilakukan telah melestarikan konsep tradisi tersebut dari generasi ke generasi.

Apartemen-apartemen yang muncul dalam Kitchin tentu tak lagi seperti kondisi rumah-rumah tradisional. Layaknya apartemenapartemen dan rumah-rumah tinggal yang dikenal saat ini, apartemen-apartemen yang ditinggali oleh para tokoh Kitchin memiliki batas-batas fisik yang jelas. Dengan adanya tembok dan pintu berkunci yang kokoh, batas menjadi berlapis, batas fisik dari konsep-konsep kolonial yang diperkenalkan oleh bangsa Barat, dan batas psikologis dalam nilai-nilai yang telah terpatri sejak lama dalam pikiran masyarakat Jepang. Sebagai konsekuensinya, ternyata ketika kondisi yang diharapkan dari satu konsep hilang maka terganggulah konsep yang lain; ketika batas fisik hilang atau tak difungsikan seperti yang seharusnya, ternyata menjadi gangguan pada rasa aman yang ditawarkan oleh rumah 
walaupun seseorang berada di dalamnya, seperti yang dikisahkan oleh Yoshimota Banana tentang apa yang dirasakan oleh Mikage sebagai berikut.

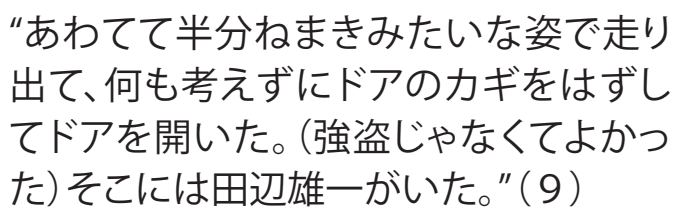

[“Terburu-buru, dengan pakaian hampir seperti baju tidur, tanpa berpikir kulepas kunci dan kubuka pintu. (Untung saja bukan maling) Kutemukan Yuuichi berdiri di sana”] (Yoshimoto, 1991: 9).

Namun, di tengah penggambaran tentang apartemen-apartemen tertutup kediaman para tokohnya, Yoshimoto Banana membuat terobosan-terobosan atas konsep rumah tertutup berbatas fisik yang kaku. Dalam novel Kitchin, di banyak kesempatan Yoshimoto menggambarkan bagaimana Mikage yang berada di dalam rumah menceritakan kondisi alam di luar rumah. Sebagai salah satu contoh tercermin dalam kutipan di bawah ini

“油が飛び散ったガス台や、さびのつい た包丁から目をあげると、空の外にはさ びしく星が光る。”

[“Saat kuangkat pandanganku dari kompor dengan percikan minyaknya, dan pisau daging yang berkarat, di luar sana kulihat bintang bersinar sunyi'] (Yoshimoto, 1991: 6).

Dengan penggambaran tentang situasi di luar rumah, Yoshimoto Banana menghadirkan suasana luar rumah di dalam rumah. Suasana di dalam rumah akhirnya bercampur dengan situasi di luar rumah, seperti suasana dapur dengan kompor dengan minyak berterbangan dan pisau berkaratnya dipadukan dengan pemandangan bintang yang bersinar, suasana dalam rumah bercampur dengan suasana langit yang mendung, pantulan diri dalam kaca jendela berbaur dengan pemandangan malam di luar rumah yang diteruskan oleh jendela yang sama, pemandangan malam membingkai tanamantanaman di bibir jendela. Dalam berbaur dengan luar, bahkan di beberapa bagian, demi memperkuat kondisi kebercampuran itu, Yoshimoto Banana menunjukkan unsur-unsur dari luar rumah ikut andil dalam membentuk kondisi dalam rumah.

Melalui penggambaran tentang bercampurnya dan ikut berperannya unsurunsur dari luar di ruang-ruang dalam rumah, Yoshimoto Banana memberikan terobosanterobosan terhadap konsep batas fisik yang jelas dan tegas dari budaya Barat. Upaya tersebut mengingatkan kembali pada kondisi rumah dengan arsitektur tradisional Jepang, dimana pada bangunan masa lalu tersebut meskipun terdapat penanda batas imajiner, namun tak memiliki batas vertikal fisik yang tegas dan tetap berupa dinding, sehingga suasana di luar rumah dapat ikut mewarnai ruang-ruang di dalam rumah.

Namun ternyata, terobosan-terobosan yang dilakukan oleh Yoshimoto Banana tak hanya pada konsep kolonial tentang batas fisik berupa dinding, ia juga memberikan perlawanan melalui kekacauan/ chaos yang dimunculkan terkait dengan batas psikologis pemisah antara uchi dan soto yang selama ini diyakini dan telah menjadi tradisi turun-temurun dalam masyarakat Jepang. Dikisahkan dalam novel Kitchin, Mikage yang belum lama mengenal keluarga Tanabe, bukan bagian dari anggota $u c h i$ bagi keluarga Tanabe, dapat bergaul akrab tanpa jarak dengan mereka sejak awal perjumpaan. Tak tercermin prinsip-prinsip terkait honne dan tate mae untuk mereka yang membedakan sikap untuk anggota uchi atau soto.

Lemahnya batas-batas psikologis yang ditunjukkan oleh Yoshimoto Banana dalam novel Kitchin berbanding terbalik dengan kuatnya peran dan kebutuhan akan batas-batas fisik. Menguatnya kebutuhan akan batas fisik diimbangi oleh Yoshimoto Banana dengan melemahnya batas psikologis, yang dalam hal ini adalah batas psikologis yang memisahkan antara uchi dari rumah, yaitu keluarga, dan soto, 
yang meliputi orang-orang di luar keluarga.

Kondisi masyarakat saat ini, terutama di kota-kota besar, yang terpisah satu sama lain karena minim ketergantungan dengan lingkungan tempat tinggalnya, semakin berjarak dengan adanya batas-batas fisik yang makin kokoh. Jarak tersebut niscaya makin akan terentang bila lapis berikutnya yaitu batasbatas psikologis juga kuat mengikat. Yoshimoto Banana melalui kekacauan yang diciptakannya berusaha memberikan pandangan-pandangan baru sebagai upaya untuk bertahan. Dilemahkannya batas-batas psikologis yang selama ini diyakini, dikendurkannya batasbatas berupa sopan-santun, kebiasaankebiasaan yang telah telah dianggap sebagai suatu hal yang seharusnya dilakukan dan yang memisahkan, membentangkan jarak antara anggota kelompok (uchi) dan non kelompok (soto). Di tengah berbagai perubahan di mana kehidupan telah banyak diambil alih oleh modernisasi dan berbagai konsep kolonial, tak ada hal lain yang dapat dilakukan kecuali berusaha bertahan dalam perubahan dan sebisa mungkin memperbaiki keadaan.

\section{Kesimpulan}

Jepang memang hanya sempat merasakan kehadiran perwakilan bangsa asing di negara mereka untuk ikut campur tangan mengawasi pemerintahan dalam waktu relatif singkat, namun kehadiran budaya asing dalam kehidupan masyarakat jauh lebih panjang, bahkan hingga kini. Budaya bangsa Barat telah mendesak budaya tradisional, konsep-konsep kolonial telah masuk dalam kehidupan seharihari masyarakat hingga ke ruang-ruang pribadi, dan diterima sebagai suatu hal yang alamiah.

Demi mempertahankan langgengnya kolonisasi, penguasa kolonial berusaha menanamkan konsep-konsep yang menguntungkan mereka, melakukan homogenisasi masyarakat terjajah ke dalam budaya yang serupa untuk mempermudah kontrol, yang dilakukan dengan idealisasi dan harmonisasi. Budaya dan konsep-konsep kolonial ditanamkan melalui idelisasi hingga dianggap sebagai hal yang ala- miah, sedangkan kondisi dan potensi kekacauan disamarkan dalam harmonisasi. Meskipun konsep-konsep kolonial tersebut bekerja, berhasil diterima masyarakat sebagai bagian hidup sehari-hari, yang menutupi konsep-konsep yang telah ada sebelumnya, namun ternyata konsep-konsep tradisi tak hilang sepenuhnya, masih meninggalkan jejak-jejak.

Rumah merupakan salah satu lokasi dimana konsep-konsep kolonial telah bekerja melalui berbagai idealisasi, harmonisasi, dan apolitisasi. Rumah dijauhkan dari hal-hal yang bersifat politis. Pandangan pascakolonial tentang ruang justru melihat rumah sebagai lokasi negosiasi antara konsep kolonial dan tradisi, dengan dimensi politis.

Setelah dilakukan analisis pada novel Kitchin karya Yoshimoto Banana, ditemukan satuan-satuan tekstual yang menunjukkan budaya dan konsep-konsep yang ditanamkan oleh penguasa kolonial. Namun demikian, budaya atau konsep tradisi yang telah ada sebelumnya tak sepenuhnya hilang karena muncul pula dalam teks. Di antara dua hal tersebut Yoshimoto Banana memunculkan juga kekacauan atau chaos dalam kisah Mikage dan tokoh-tokohnya dalam rumah di kisah Kitchin.

Konsep-konsep kolonial yang muncul di rumah dalam Kitchin menunjukkan bahwa konsep-konsep tersebut tidak ditolak. Namun, jejak-jejak tradisi yang muncul menggambarkan pula bahwa konsep-konsep tradisi pun tak ditinggalkan. Kekacauan-kekacauan yang dimunculkan kemudian mewakili gagasangagasan baru yang bukan merupakan konsep kolonial, namun juga tidak mewakili tradisi. Gagasan baru inilah yang berusaha disampaikan melalui ruang-ruang pascakolonial dalam Kitchin. Sebuah gagasan yang menolak menjadi bagian dari salah satu kubu dalam oposisi antara konsep kolonial dan konsep tradisi, menciptakan struktur baru yang tak hanya terdiri dari oposisi antara kolonial dan tradisi.

Gagasan baru yang diungkapkan oleh Banana Yoshimoto dalam ruang pascakolonialnya merupakan bentuk dari upaya untuk bertahan di tengah kondisi masyarakat 
yang telah terkolonisasi secara kultural. Masa lalu yang telah berlalu, kehidupan pada masa itu yang sepenuhnya ditata oleh konsep-konsep tradisi, tentu tak dapat kembali lagi. Yang lebih diperlukan saat ini adalah cara untuk tetap bertahan. Maka, hal tersebutlah yang berusaha ditampilkan oleh Yoshimoto Banana melalui rumah dan ruang-ruang pascakolonialnya

\section{Daftar Pustaka}

Ashihara, Yoshinobu. 1989. The Hidden Order: Tokyo Through the Twentieth Century. Tokyo \& New York: Kodansha International

Ahimsa-Putra, Heddy Shri. 2009. "Paradigma Ilmu-Ilmu Sosial-Budaya-Sebuah Pandangan". Makalah Jurusan Antropologi Budaya FIB UGM (Disampaikan dalam kuliah umum “ Paradigma Penelitian Ilmu-Ilmu Humaniora" diselenggarakan oleh Program Studi Linguistik, Sekolah Pascasarjana, UPI, Bandung, 7 Desember 2009)

Beasley, W.G. 2003. The Japanese Experience. A Short Story of Japan atau Pengalaman Jepang: Sejarah Singkat Jepang (terj.Masri Maris). Jakarta : Obor

Chilton, Myles. 2009. "Realist Magic and the Invented Tokyos of Murakami Haruki and Yoshimoto Banana," JNT: Journal of Narrative Theory, 39.3, Fall, 2009, hal. 391-415

Engel, Heinrich. 1998. A Tradition For Contemporary Architecture. Tokyo: Charles E. Turtle Company, Inc.

Faruk, Dr. 2007. Belenggu Pasca-Kolonial: Hagemoni dan Resistensi dalam Sastra Indonesia. Yogyakarta: Pustaka Pelajar Offset . 2012. Metode Penelitian Sastra: Sebuah Penjelajahan Awal.Yogyakarta: Pustaka Pelajar

Foulcher, Keith dan Tony Day (ed). 2008. Clearing a Space: postcolonial readings of modern Indonesian Literature atau Sastra Indonesia Modern: Kritik Postkolonial (terj. Kaesalah Soebagyo Toer dan
Monique Soesman). Jakarta : Yayasan Obor dan KITLV-Jakarta

Fukutake, Tadashi. 1981. Nihon Shakai no Kōzō atau The Japanese Social Structure (terj. Ronald P.Dore). Tokyo : University of Tokyo Press

Gandhi, Leela. 2006. Postcolonial Theory A Critical Introduction atau Toeri Poskolonial: Upaya Meruntubkan Hegemoni Barat (terj. Yuwan Wahyutri dan Nur Hamidah). Yogyakarta : Penerbit Qalam

Hane, Mikiso. 1992. Modern Japan: A Historical Survay. USA: Westview Press

Hendry, Joy. 1987. Understanding Japanese Society. New South Wales: Croom Helm Ltd.

Immery, Tien. 2004. Kicchin (キッチン) karya Yoshimoto Banana: Pemaknaan Ala Semiotika Riffatere. Yogyakarta: Tesis Program Pascasarjana Sastra FIB UGM, tidak diterbitkan

Koizumi, Masako. 2009. "Nihon no Daidokoro 日本の台所), ” Nippon (日本) Discovering Japan, No.3, 2009 年 12 日 15 月, hal. 10-11

Loomba, Ania. 2005. Colonialism/ Postcolonialism. New York: Routledge

Miura, Akira.1979. English Loanwords in Japanese: A Selection. Rutland, Vermont, \& Tokyo, Japan: Charles E. Tuttle Company

Murakami, Fuminobu. 2005. Postmodern, Feminist, and Postcolonial Current in Contemporary Japanese Culture: A Reading of Murakami Haruki, Yoshimoto Banana, Yoshimoto Takaaki, and Karatani Köjin. New York : Routledge

Nakajima, Kazuo, William Weaver. 1996. "The Concept of Space in Modern Japan," Sage ,Volume 13 No. 4, Winter, 1996/1997, hal. 67-72

Pyle, Kenneth B. 1988. The New Generation in Meiji Japan, Problems of Cultural Identity 1885-1895 atau Generasi Muda Zaman Meiji: Pergolakan Mencari Identitas Nasional (1885-1895).( terj. Arifin Bey ).Jakarta: PT. Gramedia

Nakagawa, Takeshi. 2005. Japanese House in 
Space, Memory, and Language. Tokyo: International House of Japan

Rao, Peggy Landers, Jean Mahoney 1990. Japanese Accents in Western Interiors. Tokyo: Shufunitomo.Co.Ltd

Reschauer, Craig. 1978. Japan: Tradition and Transformation. Boston: Houghton Mifflin Company

Treat, John Whittier. 1993. "Shojo Culture and the Nostalgic Subject," Journal of Japanese Studies, Volume 19 No. 2, Winter, 1996/1997, hal. 353-387

Upstone, Sara. 2009. Spatial Politics in Postcolonial Novel. England: Ashgate Publishing Company .2007. "Domesticity in Magical-Realist Postcolonial Fiction: Reversals of Reperestation in Salman Rusdie's "Midnight's Children"” Frountiers: A Journal of Women Studies, Vol. 28 No.1/2, Domestic Frontiers: The Home and Colonization (2007).pp.260-284. Nebraska: University of Nebraska Press

Waley, Paul. 1984.Tokyo Now \& Then: An Explorer's Guide. Tokyo: John Weatherhill, Inc., of New York and Tokyo

Whitaker, Donald P. 1990.Japan: A Country Study. Washington DC: U.S. Government Printing Office

Yoshimoto, Banana. 1991. Kicchin (キッチン). Tokyo: Fukutakeshoten(福武書店)

\section{Sumber Internet}

http://www.yoshimotobanana.com 